\title{
狭水路における速力規制の功罪検証
}

\section{朴 㮡守*·井上 欣三** \\ Verification of the Merits and Demerits of Speed Control in Narrow Waterway}

\author{
Young-soo PARK and Kinzo INOUE
}

\begin{abstract}
Speed Control has been considered to be a useful measure to improve the safety of navigation in narrow waterway. According to the simulation analysis, it becomes clear that the speed control doesn' $t$ always bring merit in safety, it also produces demerit in ship handling difficulty that imposes on mariners.

Although the speed control may decrease the chance of overtaking when the legal control of speed limitation is imposed, but it makes the elapsed-time to overtake more longer in case of heavy traffic. In the present paper, the quantitative evaluation has been done to verify the merits and demerits of the speed control by introducing Environmental Stress Model.

\section{1.はじめに}

日本の海上交通安全法では、浦賀水道、中の瀬航 路、伊良湖水道、水島航路の全区間と備讃瀬戸東航 路、備讃瀬戸北航路、備讃瀬戸南航路の定められた 区間では、船舶は12ノットを越える速力で航行して はならないと定められている。これは、日本の狭水 路における航行速力規制の原点となっている。

しかし、この速力規制が大型化・高速化する船舶 に操船上の負担を課すことや航行速力の上限を一律 に抑える事から生じる交通の団子状態が長時間にわ たって操船者に精神的な負荷を課すことなどから、 運航実務者からは、航行速力規制の効果や意義に疑 問が呈され、この制限の緩和や撤廃を望む声も出始 めていることも事実である。

このように操船実務者が経験的に感じる操船困難 性や身をもって体験する精神的負荷は主観的な言葉 による表現では一般的に理解されにくい。そこで、 本研究では、従来から実施されてきた12ノット速力 規制が、操船者にどのようなメリットをもたらし、 または、どのようなデメリットを課しているものか

を、環境ストレスモデル(1) を導入して客観的に功罪 検証することを試みた。

\section{2. 海上交通シミュレーション}

\section{1 狭水路の設定}

日本の狭水路の特徵としてよく見られるように、 水路の途中に島や浅瀬などがあって、これらによっ て水路の一部分が挟まれるような水路を考之る。こ のような障害物は細長い横長の矩形の島で模擬し た。

図 1 に、功罪検証のための評価対象狭水路の模式 困を示す。水路の長さは 7 マイル、水路の幅は 400

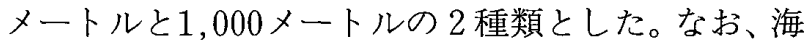
上交通シミュレーション実施にあたっては、全体で 14マイルの区間をシミュレーションエリアとした。

\section{2 交通流の生成}

（1）ランダム交通流の生成

まず、図1に示したゲートラインAにおいて一様 乱数を用いて船の発生位置を決める。次いで、ゲー トライン BおよびゲートラインCにおいて同様に一 様乱数を用いてその船の通過位置を決め、これら 3
\end{abstract}




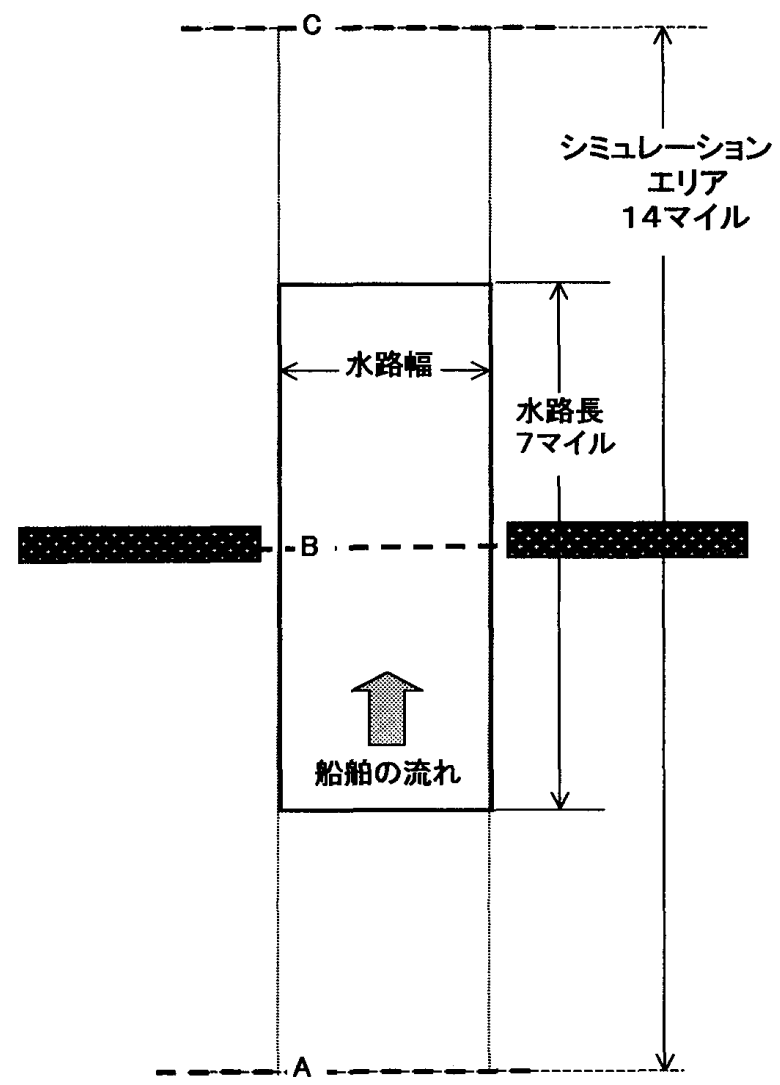

図 1 評価対象狭水路

点を結ぶ直線上を航行させる。このような方法で 次々と各船舶に航行ルートを与える。なお、船舶の 通航方向は北航の一方通航とした。

(2) 船舶発生隻数と船型構成

発生させる船舶隻数は 10 隻／時、20隻／時、30隻／ 時の 3 種類とし、船型は表 1 に示すような 8 種類に 区分した。表 1 には、船舶明細書(2) 記載の船舶につ いて各船型区分ごとに平均船長と標準偏差を求めた 結果と各船型区分ごとの構成割合も併せて示してい る。各船型区分ごとの構成割合は平成11年度に害施 された瀬戸内海備讃瀬戸水域に扔ける交通実態調査 結果 ${ }^{(3)}$ を参照したものである。なお、発生船舶の船 型区分は表 1 の構成割合に応じて割り当て、大きさ の属性は各船型区分ごとの平均全長と標準偏差のも とで正規乱数を用いて、各船ごとに与えた。

(3) 航行速力分布

発生船舶に割り当てる航行速力は、表 1 に示した 各船型区分ごとの平均速力と標準偏差のもとで正規 乱数を用いて、各船ごとに与えた。表 1 に示した各 船型区分ごとの航行速力の統計データは平成11年度 に実施された瀬戸内海備讃瀬戸水域における交通実 態調査結果( ${ }^{(3)}$ 参照したものである。

(4) シミュレーション時間

海上交通シミュレーションの実施にあたっては合
表 1 発生船舶の船型構成及び全長、速力

\begin{tabular}{|c|c|c|c|c|c|}
\hline 船型区分 & \begin{tabular}{|c} 
平均全長 \\
(m) \\
\end{tabular} & $\begin{array}{c}\text { 全長 } \\
\text { 摽準桷差 }\end{array}$ & $\begin{array}{c}\text { 秎型棰成 } \\
\text { 此率 }\end{array}$ & $\begin{array}{c}\text { 平均速力 } \\
\text { (kts) }\end{array}$ & 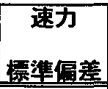 \\
\hline 20～100GT末满 & 15.2 & 5.6 & $27.1 \%$ & 10.6 & 2.4 \\
\hline 100 500GT末满 & 52.4 & 13.2 & $46.9 \%$ & 10.7 & 2.3 \\
\hline 500 1000GT末满 & 70.4 & 7.5 & $3.6 \%$ & 11.7 & 2.5 \\
\hline 1000 3000GT未満 & 90.8 & 10.4 & $13.8 \%$ & 11.7 & 2.5 \\
\hline 3000 6000GT未満 & 114.6 & 46.5 & $1.5 \%$ & 13.1 & 2.7 \\
\hline 6000 10000GT末満 & 141.2 & 12.6 & $1.7 \%$ & 13.1 & 2.7 \\
\hline 10000 20000GT未满 & 174.1 & 15.9 & $4.0 \%$ & 13.1 & 2.7 \\
\hline 20000GT以上 & 266.0 & 44.0 & $1.4 \%$ & 13.1 & 2.7 \\
\hline
\end{tabular}

計 7 時間分を生成し、このうち最初の 1 時間と最後 の 1 時間を除いた 5 時間の交通流データを使用し た。なお、結果の信頼性を向上させるために、ここ では、7 時間のシミュレーションを乱数の初期值を 変えながら合計 5 回行って、都合25時間分のデータ を求めた。ただし、分析に際しては 5 時間平均に引 き直して整理している。

（5）速力規制の実施

困 2 は、船舶隻数を 10 隻／時、20隻／時、30隻／ 時としたときに、コンピュータ上に発生した 5 時間 分の全発生船舶の速力分布を示したものである。速 力規制の実施にあたっては、各船舶に与えられた速 力属性が12ノットを越えるものには速力 12 ノットを 与え直して航行させることとした。左列の図は速力 規制がないときの速力分布であり、右列の図は 12 ノット速力規制後の速力分布である。

\section{3 環境ストレスモデル(1)による評価}

ここでの海上交通シミュレーションにおいては、 避航を考慮しないシミュレーションを実施した。こ
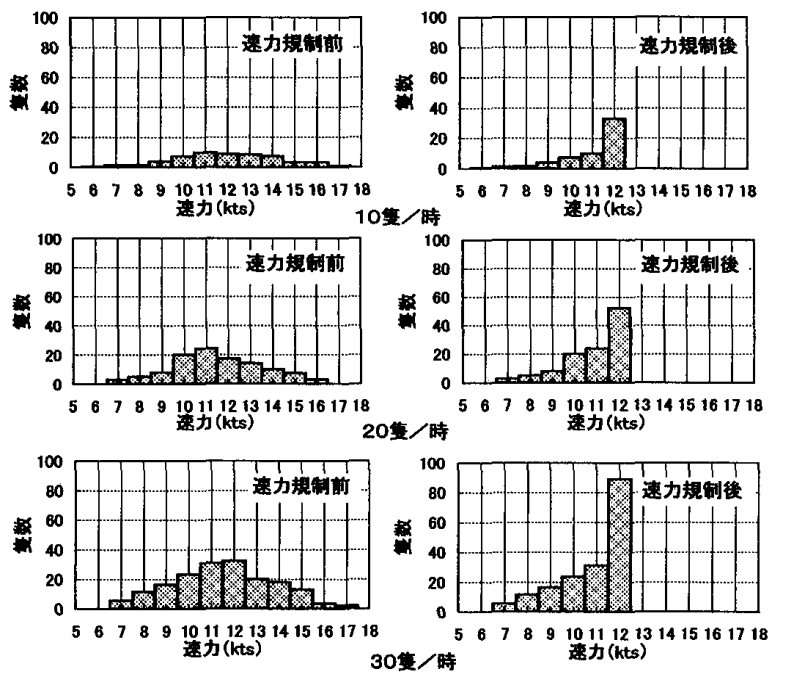

困 2 発生船舶の速力分布 
のシミュレーション結果に対し環境ストレスモデル を適用すると、いわゆる潜在環境負荷(4) が求まり、 操船者に課される操船の潜在的困難性が速力規制の 有無によってどのように相違するかが評価できる。 ここに、潜在環境負荷の大きな値は避航操船の必要 性を示唆するものといえる。

本研究では、狭くて長いいわゆる長大水路を対象 にしているので、水路内での船舶の出会いの形態は すべてが追い越し、追い越され、または、並走と考 えてよい。一般に、速力規制がなく各船が自由に才 リジナル速力で航行する場合は、船舶間の相対速力 が大きいので追い越し関係は短時間で解消される が、速力規制によって通航船舶の速力が狭い範囲に 収斂すると、船舶間の相対速力は小さくなるので追 い越し状態が長く継続することになったり、場合に よっては極めて小さな相対速力の船同志が互いに他 を囲むように団子状態で並走する状態が現れたりす ることが予想される。

Goodwinら ${ }^{(5)}$ は、速力規制をすることによって、 これまで出会うことなく通過するはずのものが、自 船速力の減少により他船と出会う機会が多くなっ て、より多くの負荷がかかることにより、その結果、 航行安全に逆の効果がでると述べている。すなわち、 海上交通の面からみれば早い速力で航行する船舶を 無理に規制する必要はないという考え方である。

そこで、ここでは、速力規制に伴う出会い形態の 質的変化、量的変化が操船者にどのような負荷をも たらすことになるかを分析することを目的に、環境 ストレス值750以上の許容できない負荷が課される 状態が出現する頻度と継続時間に着目して、速力規 制の功罪検証を試みた。

\section{3 . 速力規制の有無と操船困難性}

\section{1 速力規制実施前後における追い越し状況の 変化}

5 時間のシミュレーション評価対象時間内におけ る追い越し、追い越され、並走の発生状況が12ノッ 卜速力規制の実施前と実施後とでどのように違いが あるかを分析した。分析にあたっては、評価対象狭 水路を通過する間に環境ストレス值750以上が課さ れた状態を 1 船ごとに抽出し、その回数と継続時間 を分析の基礎デー夕とした。図 3 は、 1 隻の船が狭 水路を通過し終えるまでの間にその船に課された環 境ストレスの時系列データの例を示している。

1 船ごとに課された環境ストレス值750以上の データは、大別すると、短時間に終了する追い越し または追い越され状態、長時間持続する追い越しま

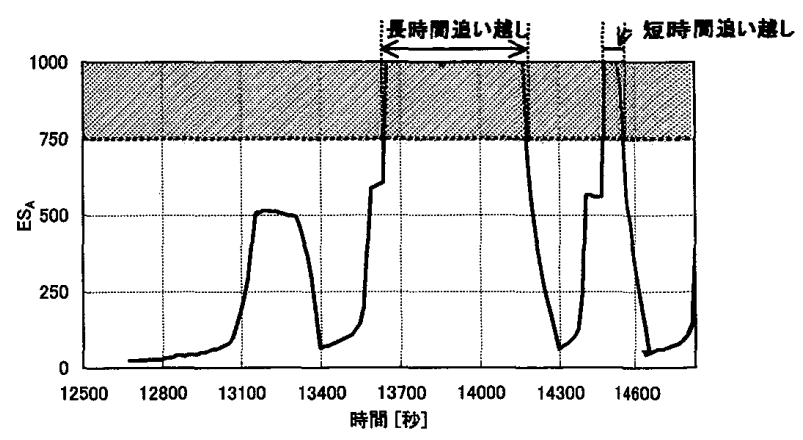

図 3 狭水路航行中の環境ストレス值

たは追い越され状態、さらには長時間にわたる並走 状態に類別できる。これらの類別は、環境ストレス 值750以上が出現した継続時間で分類し、今後、5分 以内を短時間の追い越しまたは追い越され、5 15 分を長時間の追い越しまたは追い越され、15分以上 を並走として分類する。

図 4 は、12ノット速力規制の実施前後における追 い越し等（追い越し、追い越され、並走のすべてを 含む）の発生状況の相異を 5 時間のシミュレーショ ン評価対象時間内における総出現回数で量的に比較 したものである。また、図 5 は、12ノット速力規制 の実施前後における相異を 5 時間のシミュレーショ ン評価対象時間内における追い越し等の継続時間の 総計で質的に比較したものである。

园 4 および図 5 によると、評価対象狭水路におい て生じる追い越し等の頻度の面からみると、12ノッ 卜速力規制実施後は追い越し等の発生頻度の減少傾 向は明らかである。一方、評価対象狭水路において 生じる追い越し等の総継続時間は 12 ノット速力規制 の笑施前後において明確な増減変化の傾向は見られ

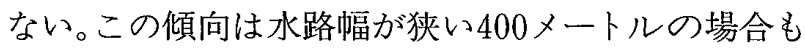

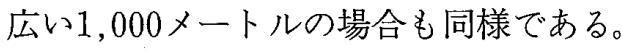

この図 4、図 5 の結果を総合してみると、速力規 制実施前後における追い越し等の質的変化は、1 回 当たりの追い越し等に要する平均所要時間の相違に みられるかもしれない。このような観点から 1 回あ たり平均追い越し時間のデー夕を表 2 に整理した。

表 2 をみてわかるように、速力規制の実施は、追 い越し等の機会を減少させる代わりに、個々の追い 越し等の 1 回あたり所要時間が平均的に長くなると いう質的変化をもたらすという特徵を見いだせる。 追い越しの出現頻度はばらつきはあるものの速力規 制の実施によって大まかにみて $15 \sim 25 \% の$ 減少、追 い越しに要する平均時間は大まかにみて $20 \%$ の増加 とみることができる。

また、長大水路における交通量の增加は、速力規 

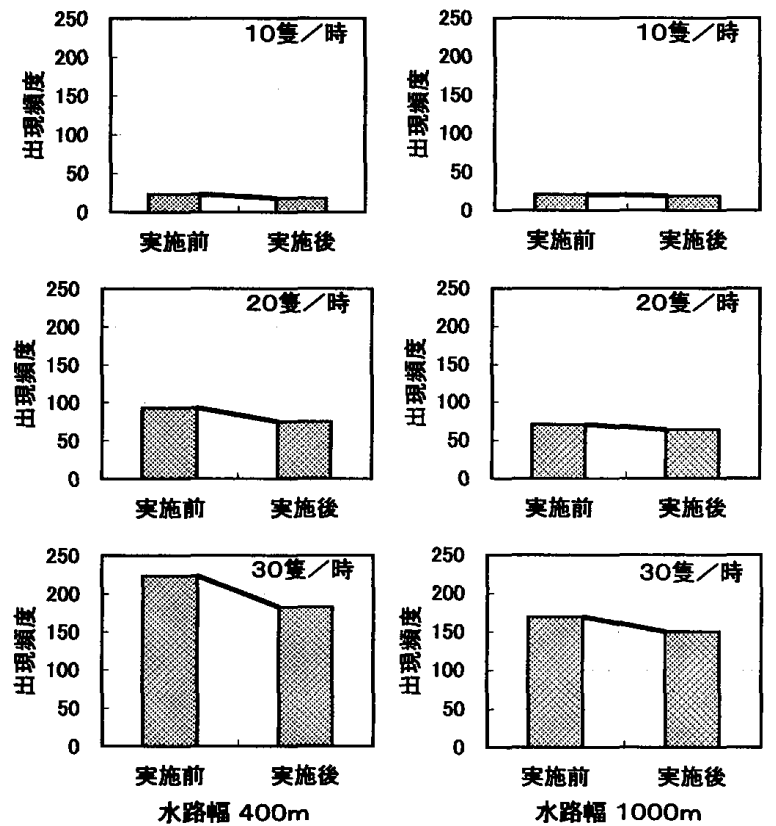

図 4 速力規制実施前後の追い越しの出現頻度

表 2 一様分布で航行する時の速力規制実施前後に おける平均追い越し時間

\begin{tabular}{|c|c|c|c|c|c|c|c|}
\hline \multirow{2}{*}{ 水路幅 } & \multirow{2}{*}{$\begin{array}{l}\text { 交通量 } \\
\text { (集/時) }\end{array}$} & \multicolumn{3}{|c|}{ 速力規制前 } & \multicolumn{3}{|c|}{ 速力規制後 } \\
\hline & & 出現頻度 & 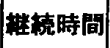 & 平均 & 出現頻度 & 継䌇時間 & 平均 \\
\hline \multirow{3}{*}{$400 \mathrm{~m}$} & 10 & 23.6 & 29.1 & 1.2 & 18.0 & 29.0 & 1.6 \\
\hline & 20 & 92.8 & 147.8 & 1.6 & 74.8 & 158.8 & 2.1 \\
\hline & 30 & 222.6 & 408.2 & 1.8 & 182.0 & 397.1 & 2.2 \\
\hline \multirow{3}{*}{$1000 \mathrm{~m}$} & 10 & 20.6 & 17.8 & 0.9 & 18.6 & 18.0 & 1.0 \\
\hline & 20 & 70.2 & 91.2 & 1.3 & 63.4 & 93.2 & 1.5 \\
\hline & 30 & 169.6 & 267.9 & 1.6 & 149.6 & 267.7 & 1.8 \\
\hline
\end{tabular}

制の有無にかかわらず、追い越し等の機会の増加を もたらすと同時に、個々の追い越し等の 1 回あたり 所要時間も平均的に長くなるという特徵も見いだす ことができる。具体的には、交通量が時間あたり 10 隻増えるごとに追い越し発生頻度は約 3 倍に、そし て、追い越しに要する平均時間はばらつきはあるが、 時間あたり交通量10隻増加に対して大まかにみて 25\%増と読み取ることができる。

なお、これらの特徴は水路幅が狭い 400 メートルの

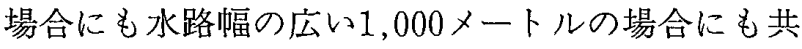
通する特幑である。

\section{2 速力規制を受ける船と受けない船に課され る負荷の相違}

図 6 と図 7 は、12ノット以上の航行速力を有する 船が評価対象水域に扔いて速力の上限を12ノットに

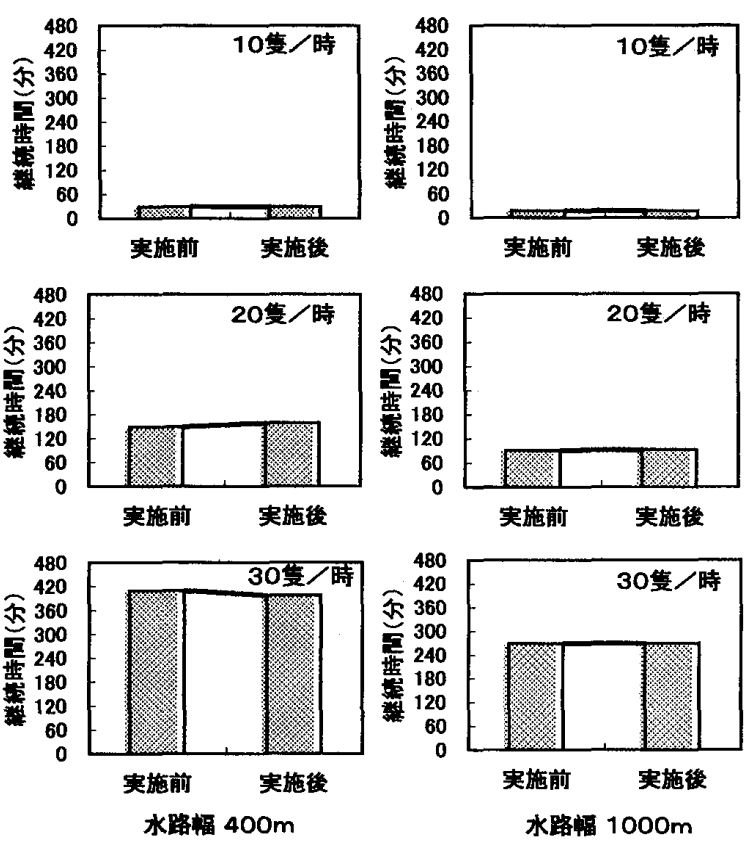

図 5 速力規制実施前後の追い越しの継続時間

制限される場合、このような速力規制を受ける船に はどのように負荷が課されるか、また、速力規制の 対象にならない航行速力 12 ノット以下の船にとって 負荷はどのように異なるのかを、規制実施前後で比 較したものである。

横軸には、追い越しの継続時間をとっているが、 これらは、先にも述べたように評価対象水域を通過 する間に 1 船ごとに課された環境ストレスの時系列 データにおいて、ストレス值750以上のデータをその 継続時間によって、5 分以内を短時間で終了する追 い越しまたは追い越され、5〜15分を長時間の追い 越しまたは追い越され、15分以上を並走として分類 している。

ここでは400メートル狭水路の交通量30隻/時の 場合のみを揭載したが、規制実施前に比べて規制実 施後においては規制を受ける船も規制を受けない船 も短時間追い越しの発生頻度がともに減少するが、 規制を受けない船に関する短時間追い越しの機会減 少の特徵が顕著である。

一方、長時間追い越しの出現頻度は規制実施前に 比べて規制実施後においては規制を受ける船も規制 を受けない船も暫增の傾向が見られる。ただし、追 い越しの継続時間の面からは規制を受ける船に関す る追い越しの長時間化が特徵として上げられる。

なお、これらの傾向はこれ以外の条件における結 果にも共通するものであるが、このように交通が輻 輳する狭水路では速力規制の実施は長時間にわたる 追い越しや追い越されの機会を増加させる形で、規 

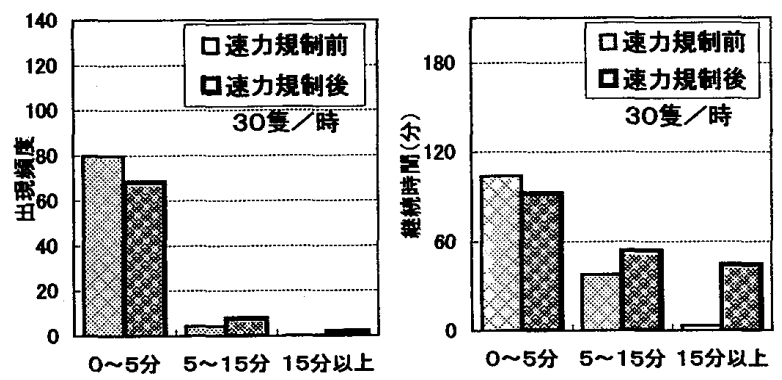

図 6 規制を受ける船に課される負荷 (水路幅 $400 \mathrm{~m}$ )

制を受ける船に負荷を課すことになるといえる。

短時間に追い越しが完了するか、長時間追い越し 状態が継続するか、さらには、長時間並走状態がつ づくかは、要は関係する船舶同士の相対速力に低存 する。したがって、速力規制は航行船舶の相対速力 を小さくするという点からみれば、これまでオリジ ナル速力で短時間に他船を追い越してきた船に対し 追い越し時間の長時間化という形で負荷を課すこと になるのは当然である。

\section{4. 正規分布で航行する場合の負荷}

\section{1 速力規制実施後における追い越し等の出現 頻度と継続時間、一様分布と正規分布の場合 の比較}

ここまでの分析では、困 1 に示したようにゲート ラインA、B、C、における船舶の通過位置は一様乱 数を用いて決定していた。ここでは、『狭水路におけ る航跡分布は正規分布をなす』という一般的特性 ${ }^{(6)}$ に従って、各ゲートライン上での通過位置を正規乱 数を用いて決定し、実際に近い航行状態のもとで追 い越しに伴う負荷がどのように変化するかを分析し た。なお、ここでの分析には速力規制実施後の状況 を対象にした。

図 8 は、12ノット速力規制実施後における追い越 し等(追い越し、追い越され、並走のすべてを含む) の発生状況を、一様分布で航行する場合と正規分布 で航行する場合とで比較したものである。左列の図 は 5 時間のシミュレーション評価対象時閒内におけ る追い越し等の総出現回数、また、右列の図は継続 時間の総計で比較したものである。

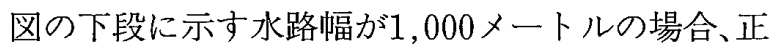
規分布で航行するときは一様分布で航行するときよ りも追い越し等の出現頻度も継続時間も明らかに増 加し、特に交通が輻輳するとこれらの増加傾向が顕

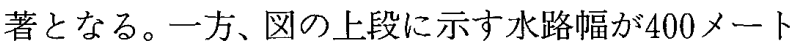
ルの場合は、追い越し等の出現頻度も継続時間もさ ほど顕著な増加傾向はみられない。
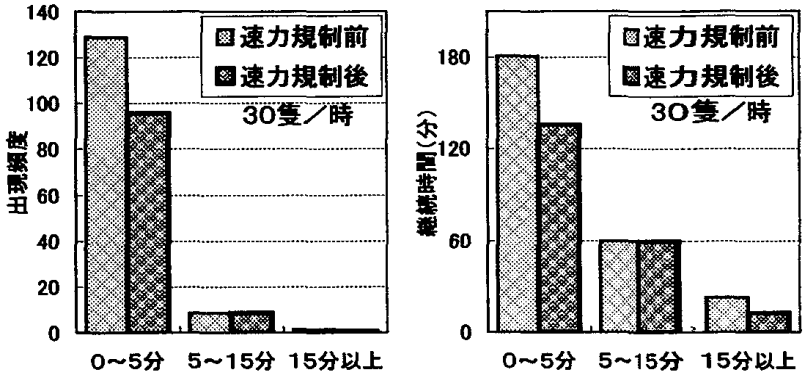

図 7 規制を受けない船に課される負何 (水路幅 $400 \mathrm{~m}$ )
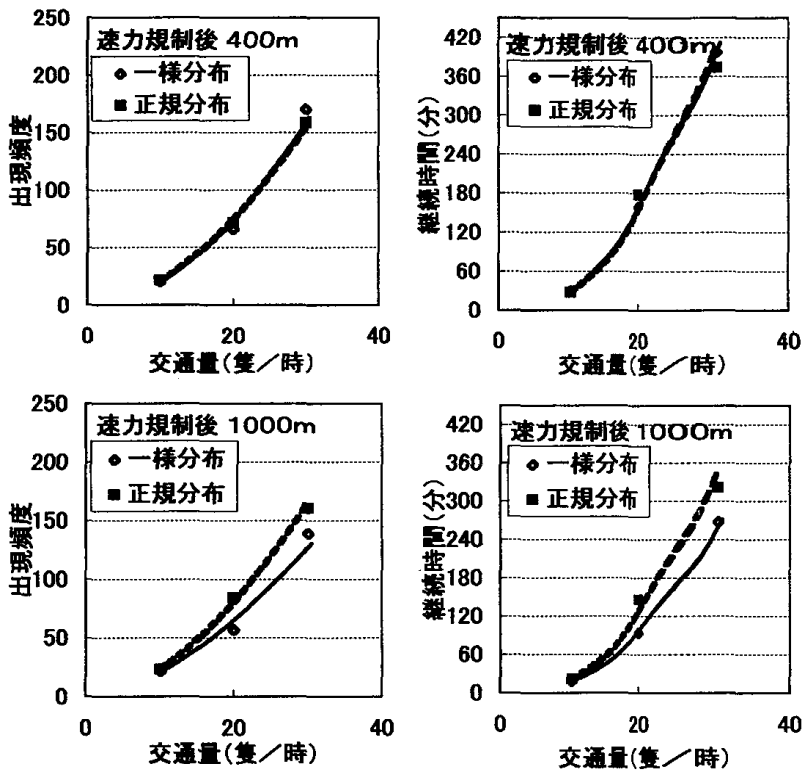

図 8 速力規制実施前後における追い越し状況 （一様分布と正規分布の場合の比較）

このことは、水路幅が狭いときは一様分布で航行 している状態でも船同士の左右距離が近くなること が多いので、もともと追い越し状態が生しる穖会が 多かったことに起因している。一方、水路幅が広い 場合は、水路一杯に分散して航行していたものが水 路の中央寄りに航行することになるので追い越しの 機会が顕著に増加することになる。

\section{2 速力規制実施前後における平均追い越し時 間}

表 3 は、実際の状態に近い航行状態と考えられる 正規分布で航行する場合、速力規制実施前後におけ る追い越し等（追い越し、追い越され、並走のすべ てを含む）の1回あたり平均追い越し時間のデー夕 を整理したものである。

速力規制の実施は、正規分布で航行する場合にも 一様分布で航行する場合と同様に、追い越し等の発 生回数を減少させる一方で、1回あたり追い越し等 の平均時間が長くなる傾向がみられる。具体的な追 い越しの出現頻度の減少率（大まかにみて15～25\% 
表 3 正規分布で航行する時の速力規制実施前後に おける平均追い越し時間

\begin{tabular}{|c|c|c|c|c|c|c|c|}
\hline \multirow{2}{*}{ 水路愊 } & \multirow{2}{*}{$\begin{array}{l}\text { 交通量 } \\
\text { (隻/時) }\end{array}$} & \multicolumn{3}{|c|}{ 速力規制前 } & \multicolumn{3}{|c|}{ 速力規制後 } \\
\hline & & 出現頻度 & 胜槙時間 & 平均 & 出現頻度 & 継䌇時間 & 平均 \\
\hline \multirow{3}{*}{$400 \mathrm{~m}$} & 10 & 25.8 & 35.7 & 1.4 & 18.4 & 26.8 & 1.5 \\
\hline & 20 & 94.2 & 158.0 & 1.7 & 72.8 & 178.1 & 2.4 \\
\hline & 30 & 193.8 & 345.1 & 1.8 & 147.4 & 373.0 & 2.5 \\
\hline \multirow{3}{*}{$1000 \mathrm{~m}$} & 10 & 27.8 & 27.7 & 1.0 & 22.6 & 21.3 & 0.9 \\
\hline & 20 & 95.6 & 126.8 & 1.3 & 85.6 & 145.8 & 1.7 \\
\hline & 30 & 176.6 & 282.3 & 1.6 & 149.6 & 321.3 & 2.1 \\
\hline
\end{tabular}

の減少）と追い越しに要する平均時間の増加率（大 まかにみて $20 \%$ 増加）は一様分布の場合とほぼ同 様である。

な拉、表 2 との比較からは、一様分布で航行する 場合上り正規分布で航行する場合の方が 1 回あたり 追い越し等の平均継続時間は約 $10 \%$ 弱長くなるよう である。

\section{3 船型による負荷の相異}

速力規制の実施によって船型ごとに課される負荷 に違いがあるかどうかを12ノット速力規制実施前後 において比較した。船型は小型船、中型船、大型船 に分類し、20総トン〜 1,000総トンを小型船、1,000 総トン〜 10,000総トンを中型船、10,000総卜ン以上 を大型船とした。それぞれの船型別構成割合は、小 型船は78.6\%、中型船は $16.0 \%$ 、大型船は $5.4 \%$ であ る。

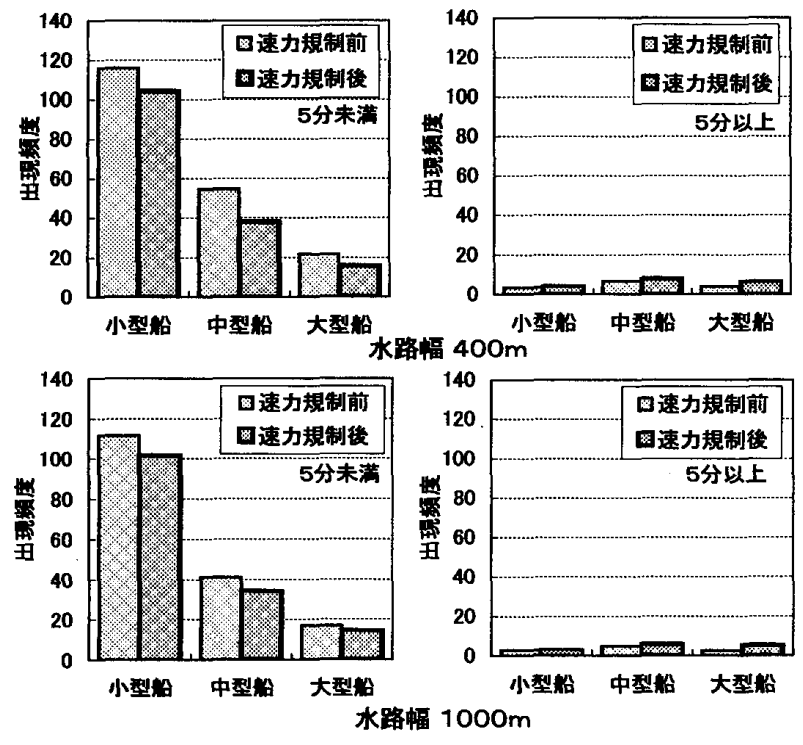

図 9 速力規制による船型別負荷増減変化 (出現頻度)
図 9、図10は、30隻／時の交通量が正規分布で航 行する条件において、5 時間のシミュレーション評 価対象時間内の追い越し等(追い越し、追い越され、 並走のすべてを含む）の総出現回数と追い越し等の 継続時間の総計をとりまとめたものである。図の上

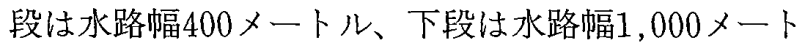
ルの場合である。なお、追い越し状況については 5 分以内の短時間追い越しと 5 分以上の長時間追い越 しの 2 種として取りまとめた。

速力規制実施前後を比較すると、いずれの水路幅 の条件においても、また、いずれの船型においても 速力規制実施前に比べ速力規制実施後は追い越しの 出現頻度の面からは短時間追い越しの減少、長時間 追い越しの增加が明らかである。また、追い越しの 継続時間の面からも短時間追い越しでは水路幅 1,000メートルではやや横ばい傾向がみられるもの

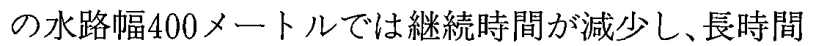
追い越しではいずれの水路幅の場合も継続時間が増 加する傾向が明らかである。そして、船型ごとに課 される負荷の違いに関しては、船型が大きくなるほ ど長時間追い越しの継続時間が大きくなる傾向が見 られる。

\section{5. 結 論}

狭水道における航行の困難性の面からみると、追 い越しの頻度と追い越し状態の継続時間の長さが操 船に困難をもたらす原因となる。速力規制の有無に かかわらず交通輻輳は追い越しの機会の増加と平均 追い越し時間の長時間化をもたらすことは表 2 (一


図10＼cjkstart速力規制による船型別負荷増減変化 (継続時間) 
様分布の場合)、表 3 (正規分布の場合) に示した数 值結果からも明らかである。一般に交通量が時間あ たり10隻増えるごとに追い越し発生頻度は 3 倍に、 そして、追い越しに要する平均時間はばらつきはあ るが時間あたり交通量10隻増加に対して大まかにみ て25\%增しとみることができる。

しかし、航行速力の上限を一律に抑える速力規制 は、追い越し機会の減少をもたらす反面追い越し時 間に要する時間の長時間化を招くことになる。速力 規制は航行船舶の相対速力を小さくする施策である ことからすればこれは必然である。

しかし、このような操船者に困難をもたらすよう に見える速力規制の施策はこれまで国内各所の狭水 道において安全対策の手段として導入されてきた が、この速力規制は明らかに追い越し機会の減少効 果をねらった施策であったと考えて良い。

確かに 2 隻の船だけの追い越し関係に着目する限 ク、追い越し機会が減れば安全は増すとの図式が描 ける。つまり2隻の船が十分な間隔をあけて航行で きるなら 2 隻の船の相対速力が小さいほど追い越し の発生機会は限られるので安全なことは明白であ る。

しかしながら、交通が輻輳する場合はどうか。交 通が輻輳すると 2 隻の船の関係が多数の船との関係 となる。船と船の間隔を十分にあけて航行すること ができなくなると、結局、長時間を要する追い越し や団子状態での長時間航行を余儀なくされ、本来の 速力規制のねらいとは逆の面が表面化することにな る。

近年、運航実務者から速力規制の効果や意義に疑 問が投げかけられるのは、この点を指摘するもので あろう。

本研究では、日本において実施されてきた 12 ノッ 卜速力規制が操船者にどのような負荷を課すかを、 環境ストレスモデルを導入して客観的に検証した。 その結果、交通が輻輳すると、(1) 速力規制の実施は、 追い越しの機会を減少させる代わりに、1 回あたり 追い越し所要時間が平均的に長くなるという質的変 化をもたらす。(2)追い越しの出現頻度は速力規制の 実施によって大まかにみて15～25\%減少し、平均追 い越し時間は大まかにみて $20 \%$ 増加する。(3)速力規 制の笑施は、長時間にわたる追い越しの機会を増加 させる形で、特に速力規制を受ける船に負荷を課す ことになる、ことがわかった。

以上のように、速力規制実施に伴う困難性は長い 時間を要する追い越しや並走の増加に現れ、そして、 追い越しに機会や追い越しに要する時間の増加は交
通量の増加に比例する。このように速力規制の功罪 は交通輻輳の条件に左右されるものであることが明 らかになった。

\section{参 考 文 献}

（1）井上欣三・増田憲治・世良 亘：海上交通安全 評価のための技術的がイドライン策定に関する 研究一I 。一環境負荷の概念に基づく操船の困 難性評侕一, 日本航海学会論文集, 第98号, pp. 225-234 (1998)

（2）日本海運集会所：日本船舶明細書，内航船舶明 細書

（3）日本海難防止協会 - 本州四国連絡橋公団：南北 備讃瀬戸大橋の緩衝工に関する調查椎討報告 坒，pp.16-31，平成11年12月.

（4）井上欣三・川瀬雅勇已・安田 克・原大地： 海上交通安全評価のための技術的ガイドライン 策定に関する研究一III. 一困難性評価とヒュー マンファクター一，日本航海学会論文集，第100 号, pp.191-198(1999).

(5) E. M. Goodwin, J. F. Kemp and W. G. P. Lamb. "Speed Control as a Factor in Marine Traffic Management", the Fifth International Symposium on Vessel Traffic Services, April 1984.

(6) 井上欣三：直線航路における航跡分布のモデル 化と航路分離に関寸る一考察，日本航海学会論 文集，第56号，pp.103-115(1977)。

\section{質 疑 応 答}

稲田健二(海上保安行)：シミュレーションの前提と して、個々の船舶の操縦性能を加味しているのか をご教示下さい。功罪検証をする上においては検 討に值するものと思います。

朴 榮守：本研究では、個々の船舶に課される潜在 的な困難性を評価しています。潜在環境負荷の大 きな值は、他船や障害物を避けるための操船行動 の必要性を意味するもので、したがって、このシ ミュレーションでは避航操船の必要性を示しては いますが、個々の船舶に実際の操船が行われるも のではありません。実際の操船を行ったときに課 される操縦負荷は別途操縦性能を加味して評価す ることになります。

鈴木三郎 (神戸商船大学)：制限幅のある一方向の船 舶流によるストレスモデルより反方向の同可航幅 がある場合（備讃瀬戸東航路）は、功罪はどのよ うになるでしょうか。 
朴 榮守：この場合は、本研究での出会い形態（追 い越し、追い越され、並走）に反航船との行き会 いの影響が追加される形になりますので、交通環 境ストレス值 (ESs值) が高くなることが予想され ます。このとき速力規制の有無は隣接レーンの行 き会い船との相対速力に相違が生じることになり ます。

福戸淳司 (海上技術安全研究所)：航路内において低 速船は右側、高速船又は規制上限の速度の船は左
側と言うような規制を加えた場合、環境ストレス 值が改善されるかどうか検討されていましたら、 その結果をお教え下さい。

朴 榮守：この場合も、本研究での条件に速力条件 が異なる同航船の影響が追加されるもので、交通 環境ストレス值（ESs值）が変化すると考えます。 まだ、ご指摘した条件においては検討しておりま せんが、本研究での環境ストレス值を用いて検討 できる項目であります。 